\title{
Effect of rainfall variation on yam production in Kuta, Shiroro Local Government area of Niger State, Nigeria.
}

\author{
Yahaya $^{1}$; T. I.; Tsado ${ }^{2 *}$, E.K and Odinukaeze ${ }^{1}$, N. E., \\ ${ }^{I}$ Department of Geography, School of Natural and Applied Science, Federal University of Technology, Minna, \\ Niger State, Nigeria \\ ${ }^{2}$ Department of Crop Production, School of Agriculture and Agricultural Technology, Federal University of \\ Technology, Minna, Niger State, Nigeria
}

\begin{abstract}
Agricultural production in Niger State like other states in Nigeria is highly vulnerable to climate changeability. Climate change is predicted to have adverse effects on the agricultural sector of the poorer parts of the world especially sub-Saharan Africa, The aim of the study was to assess the influence of rainfall variability on yam production in Kuta community of Niger state. For the purpose of this research, data was collected from 100 respondents through the administration of questionnaires. Rainfall data covering a period of ten years (2001-2010) was also obtained from Shiroro dam, Niger State, while the yearly yam yield for about ten years (2001 - 2010) was obtained from Niger State Ministry of Agriculture. The study evaluates the effect of rainfall variation on yam production and analysed the variability in the rainfall pattern within the study area and its effect on the yield of yam. Linear regression and standardized anomaly index were used to analysis the data gathered. Graphs and tables were used to present the results. The study showed that the variation of rainfall in the study area was minimal but a strong relationship between rainfall variation and yam yield. It also showed a positive response between that yam yield and the moderate rainfall that was well distributed.
\end{abstract}

Key words: Climate changeability; yam production

\section{Introduction}

Agriculture is the biggest single industry in many less developed countries of the world. It plays a significant role as it contributes to the national food security, national social and economic stability and also to the environmental protection of the nation. It provides not only food but also raw materials for most manufacturing industries of the country. Most countries, import and export large amounts of agricultural produces which brings about economic development of the world (Diao. 2010).

Crop production is an integral part of agriculture dealing with the cultivation, protection, harvesting and storage of cultivated plants for man's use. It is the sum total of all the activities involved in producing, preparing and processing of agricultural crops (Akanbi et. al., 2004).

Agriculture being one of the most weather-dependent of all human activities, is highly vulnerable to climate change; a variability that can have direct impact, or influence on the quantity and quality of agricultural production. The climate of an area is highly correlated to the vegetation and by extension the type of crop that can be cultivated. Nigeria's agriculture therefore depends highly on climate, because temperature, sunlight, water, relative humidity are the main drivers of crop growth and yield (Adejuwon, 2004). Climate change is also predicted to have adverse effect on the agricultural sector of the poorer parts of the world especially in subSaharan Africa (SSA). Most of the crops produced in this area are low-technology based and are therefore heavily susceptible to environmental factors, (Adejuwon, 2004).

Nigeria one of the largest countries in SSA is the major producer of yams in the world in terms of quantity, producing an average of 31 million metric tons annually. Nigeria produced $60 \%$ of the world's yams in 2010, and is the largest contributor to Africa's "yam belt," comprising Nigeria, Ghana, Benin, Côte d'Ivoire, Central African Republic, Cameroon, and Togo. They produce altogether about $92 \%$ of the world's yams. Yams have had the second highest production level of any food crop in Nigeria in the past 50 years after cassava. Evans school policy analysis and research shows that production and area harvested have grown steadily until 2006 and 2007 respectively, after which production and area harvested have shown a decline. In 2010, the gross agricultural production value for yams was $\$ 15,041$ million USD and accounted for the largest proportion of any crop in the country.

Yams are agronomically, annual rain fed crops which grow for 6-12 months depending on the cultivar, ecology and soil properties in the production area (NRCR, 1998). They serve as staple food in many tropical and even sub-tropical countries. World yam production is about 30 million tons annually with $90 \%$ grown in the yam production belts of West Africa (FAO 2002).

Yam production in Nigeria has more than tripled over the past 45 years from 6.7 million tones 1961 to 39.3 million in 2006 (FAO, 2007). This increase in output is attributed more to the large area planted with yam 
than increase in productivity (Nwosu and Okoli; 2010). Though the cultivated area to yam has increased production, however the growth rate has declined tremendously from the average $27.5 \%$ between 1986 and 1990 to $3.5 \%$ in the 1996 to 1999 periods (Ekunwe et. al., 2008). This decline in average yield per hectare has been more drastic, - from 14.9\% in 1986-1990 to 2.5\% between 1996-1999 (CBN, 2002; Agbaje et al 2005 and FAO, 2007). This trend may not be unconnected with inefficiency of use resourced and other allocations (Nwosu and Okoli, 2010). It may therefore, be important for yam farmers to manage the little resources at their disposal optimally for increased yield and sustainability of yam production, (Udoh and Akintola 2001; Etim et al., 2005; Udoh and Etim, 2007).

Inefficient use of resource and badly managed utilization can seriously jeopardize and hamper food production, availability and security (Udoh and Etim, 2007).

\section{Statement of the problem}

Apart from the hard working nature of Nigerian yam famers, climatic factors play an important role in determining the production of food crops in the semi-arid region of Africa and particularly in Nigeria. Agriculture is the economic mainstay of the majority of households in rural Nigeria (Udoh, 2005) and is a significant sector in Nigeria's economy (Amaza, 2000). Nigeria's agriculture therefore depends highly on climate, because temperature, sunlight, water, relative humidity are the main drivers of crop growth and yield. Climate change is also predicted to have adverse effects on the agricultural sector of the poorer parts of the world especially in sub-Saharan Africa (Adejuwon, 2004). Variations in the rainfall distribution of the past years have greatly affected agricultural activities.

This study seeks to therefore assess the influence of rainfall variation on yam production in Kuta community of Niger State. The specific objectives are to a) examine the variability in rainfall pattern of the study area from 2001 to 2010 ; b) examine the trend of yam production in the community and c) examine the relationship between rainfall variability and yam production of Kuta community of Niger state.

\section{Materials and Methodology}

Data used in this research work was generated from both primary and secondary source. Primary data was collected directly from the field survey and the interview administered to the farmers through the questionnaire designed.

A baseline survey was conducted at Kuta to determine the extent of yam production in the region. 100 questionnaires were administered to the farmers with the aim of finding out the influence of rainfall variation on yam production in the Community. The farmers ages ranges above 40 years and have been cultivating yam for not less than 5 years.

The sources of secondary data included journals, textbooks, encyclopaedias, news prints and consultations with officials of the Niger State Agricultural Development Project -NSADP. The NSADP provided annual yield of yam while the monthly rainfall data for 10 consecutive years, from 2001-2010, was collected from Shiroro hydro dam.

\section{Data Collection.}

All data collected were subjected to statistical analysis. Rainfall data obtained was for monthly basis for 10 years (2001 to 2010) and converted to mean annual values using the statistical technique stated below.

$$
\begin{gathered}
X \alpha=\frac{\Sigma X}{n} \\
\text { Where } \\
\quad \begin{array}{c}
\text { X } \\
n=\text { number of years } \\
\Sigma
\end{array} \\
\quad \text { summation sign }
\end{gathered}
$$

i. Standardized anomaly index was used to analyze the variability in the rainfall pattern from $2001-2010$ and to examine the trends in yam production of the study area.

The formula for the standard anomaly index is given as:-

$$
\mathrm{SAI}=\left(\frac{x-\bar{x}}{\sigma}\right)-
$$

Where

$$
\begin{aligned}
x^{-} & =\text {mean } \\
x & =\text { rainfall on yearly basis } \\
\sigma & =\text { standard deviation }
\end{aligned}
$$

ii. Linear regression was used to examine the relationship between rainfall variability and yam production of the study site. 
The formula for the linear regression was given as

$$
y=a+b x \text { - }
$$

Where:

$$
\begin{aligned}
& a=y \alpha-b x \alpha \text { and } \\
& b=\frac{N \Sigma x y-\Sigma x \Sigma y}{N \Sigma x^{2}-(\Sigma x)^{2}} \\
& y=\text { planting time of the year } \\
& x=\text { rainfall trend }
\end{aligned}
$$

\section{Statistical Analysis}

The responses from the questionnaire were analyzed statistically using descriptive statistics.

\section{Rainfall distribution in the study area.}

\section{Result and Discussions}

The rainfall distribution of the Kuta area over the study period is presented in Table 1. The data for ten years 2001-2010 is also presented as Table 2. The onset of rain in Kuta area was mostly within April/May every year, and the cessation was always within September or October. The months of July, August and September always had the heaviest rainfall, while the period of November up until the following month of March are usually rainless with occasional cold Hamattan winds. The planting of yam used to be in November through to February; but for the change in climate, yam planting time has now changed, coinciding with January or February when the hamattan season is at its peak and the soil has not heated up and in late April to early May when the initial rainfall just began and the soil is beginning to lose its heat absorbed during the months before February and March.

Table 1 Mean monthly rainfall at Kuta study area

\begin{tabular}{|l|c|}
\hline \multicolumn{1}{|c|}{ MONTH } & MEAN (mm) \\
\hline JANUARY & 0 \\
\hline FEBUARY & 0 \\
\hline MARCH & 0.27 \\
\hline APRIL & 90.45 \\
\hline MAY & 110.71 \\
\hline JUNE & 175.12 \\
\hline JULY & 259.04 \\
\hline AUGUST & 280.15 \\
\hline SEPTEMBER & 268.3 \\
\hline OCTOBER & 113.79 \\
\hline NOVEMBER & 2.45 \\
\hline DECEMBER & 0 \\
\hline
\end{tabular}

\section{Source: Field survey, 2014}

\section{Distribution of rainfall over ten years in the study area.}

Looking at the rainfall pattern of the presiding ten years - 2001 to 2010 , the rainfall distribution varied between the years. The mean annual rainfall rose from $1265.2 \mathrm{~mm}$ in 2001 to $1345.20 \mathrm{~mm}$ by 2003 and to $1833.80 \mathrm{~mm}$ in 2006. This rainfall value started decreasing from year 2007 (with $1403.80 \mathrm{~mm}$ ) till 2010 (with $1206.99 \mathrm{~mm}$ ) when the data was collected (see Table 2 and Figure 1). Of all the ten years rain distribution for 2004 was the lowest with $1020.31 \mathrm{~mm}, 2006$ had the highest rainfall.

Table 2:A ten year mean annual rainfall of the study site.

\begin{tabular}{|c|c|c|}
\hline Years & Annual rainfall in (mm) & Mean in (mm) \\
\hline 2001 & 1265.20 & 105.43 \\
\hline 2002 & 1167.90 & 97.33 \\
\hline 2003 & 1345.20 & 112.10 \\
\hline 2004 & 1020.31 & 85.03 \\
\hline
\end{tabular}


Effect of rainfall variation on yam production in Kuta, Shiroro Local Government area of Niger State,

\begin{tabular}{|c|c|c|}
\hline 2005 & 1049.15 & 87.43 \\
\hline 2006 & 1833.80 & 152.82 \\
\hline 2007 & 1403.80 & 116.98 \\
\hline 2008 & 1337.35 & 111.45 \\
\hline 2009 & 1372.90 & 114.41 \\
\hline 2010 & 1206.99 & 100.58 \\
\hline
\end{tabular}

Source: Calculated mean, (2001-2010)

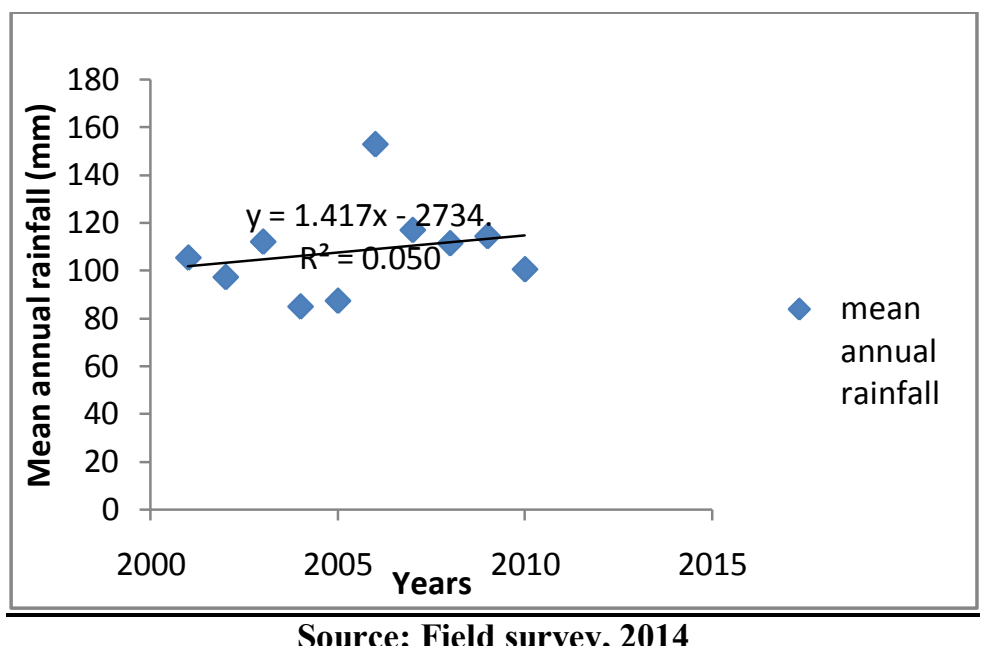

Figure 1. Pattern of mean annual rainfall of the study area

\section{Variability of annual rainfall within 10 years at the study site.}

The variability in annual rainfall at the study site for the periods of 2001 to 2010 was very minimally. This implies a little disparity in the amount of rainfall in the past ten years in the study area. Typically in 2001, the amount of rainfall was $1265.2 \mathrm{~mm}$ but this dropped to $1167.9 \mathrm{~mm}$ by 2002. It increased in 2003 to 1345.2 $\mathrm{mm}$, but fell to $1020.31 \mathrm{~mm}$ by 2004 and rose 1049.15 by 2005 . The rainfall in 2006 drastically rose to $1833.8 \mathrm{~mm}$, but fell again in 2007 and 2008. The rate of rainfall never reached the 2006 level again implying that the variation in the annual amount of rainfall in Kuta, Niger State was minimal. This also shows that the variation of the rainfall over the region in the more recent years was much higher compared with the earlier years indicating that the region become wetter. The standardized Anomaly Index - SAI value of $r^{2} 0.05$ supports this assertion.

\section{Yields of yam tubers in the ten years covering the study period.}

There was a continuous rise in the yield of yams from 2001 (11.26 tons per ha) to 2009 (16.91 tons per ha). By 2010 however a drop in yield compared with the earlier years (14.19 tons per ha) was noticed. This therefore shows that there was a minimal variation in the yield of yam in Kuta community throughout the study period - $2001-2010$. 


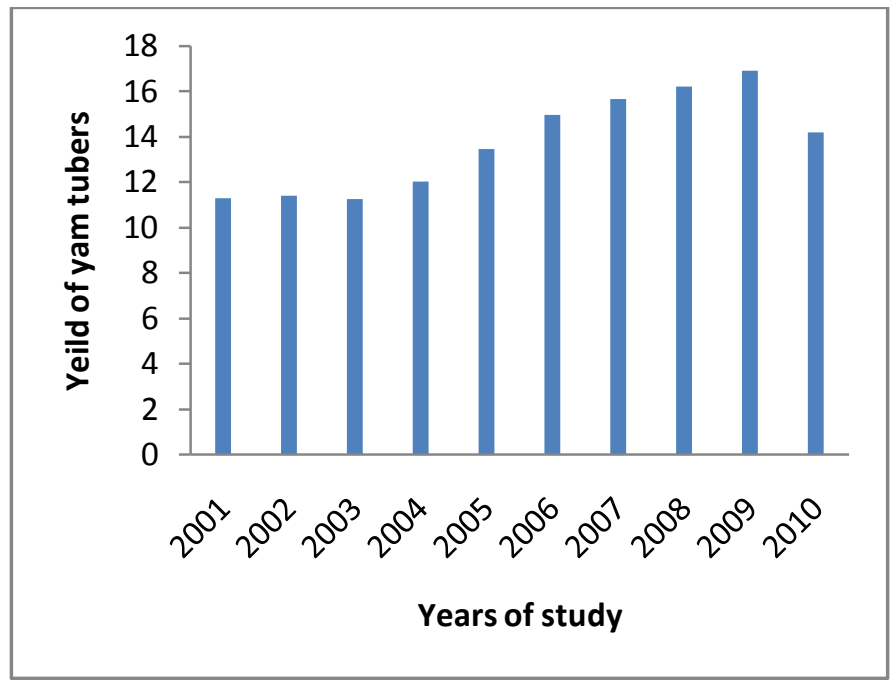

Source; Niger State Ministry of Agriculture (2001 - 2010)

\section{Relationship between the Annual Rainfall and yam yield.}

The relationship between rainfall distribution and yield of yam tubers in Kuta area of Niger State, Nigeria is presented in Table 3. A general explanation is that with the increase in the amount of rainfall received, so was a corresponding increases in tubers yield.

Table 3: Relationship between the Annual Rainfall and yam yield in the study area

\begin{tabular}{|c|c|c|}
\hline YEARS & YAM PRODUCTION IN TONS & RAINFALL (MM) \\
\hline 2001 & 11.26 & 1265.20 \\
2002 & 11.38 & 1167.90 \\
2003 & 11.23 & 1345.20 \\
2004 & 12.00 & 1020.31 \\
2005 & 13.44 & 1049.15 \\
2006 & 14.95 & 1833.80 \\
2007 & 15.64 & 1403.80 \\
2008 & 16.2 & 1337.35 \\
2009 & 16.91 & 1372.90 \\
2010 & 14.19 & 1206.99 \\
\hline
\end{tabular}

Source; Niger State Ministry of Agriculture (2001 - 2010)

In Fig 4 is shown the yield of yam and rainfall distribution varying significantly from year to year and that there was a significant relationship between yam yield and rainfall variability. The increase in yield of yam recorded in 2006-2010 may perhaps be attributed to the moderate spread of rainfall during the planting and growing seasons. The experience of low rainfall between 2001-2005, particularly during the planting and growing seasons, could affect the establishment of the crop. The period 2006-2010, was characterized by moderate rainfall that was well distributed. But after rain establishment, there must follow an evenly distributed pattern for proper tuber initiation, growth and enlargement.

Rainfall variability from season to season greatly affects soil water availability, and thus poses yam production risks. Yam formation is favored greatly by moderate rainfall that is well spread.

For maximum yield, yam requires a humid tropical environment, with an annual rainfall of over 1500 millimeters distributed uniformly throughout the growing season.

Generally, it is very clear that the total rainfall and distribution of rainfall at any location determines the length of growing season in that location. 


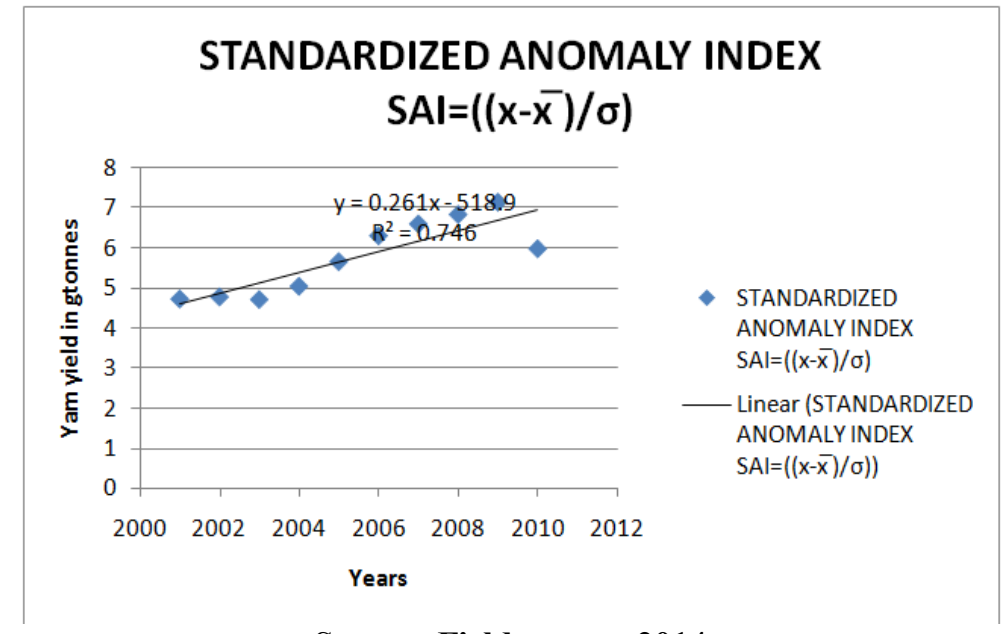

Source; Field survey, 2014

Fig, 4. Shows the trends in yam production

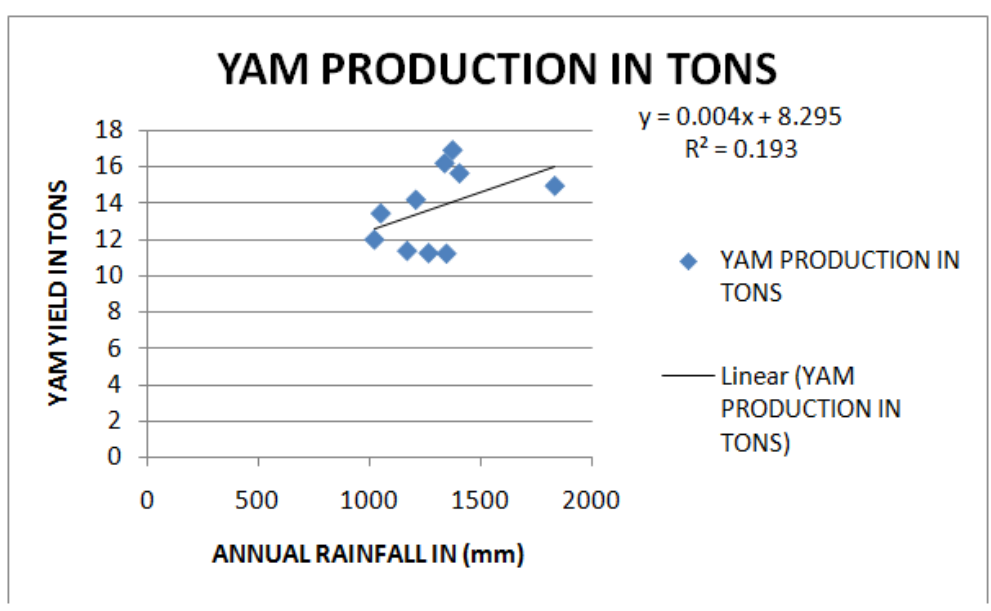

Figure 5: The relationship between the Annual Rainfall and yam yield.

\section{Summary}

This study conducted in Kuta, Niger State of Nigeria to investigate the influence of rainfall variation on yam production, showed that the annual rainfall for the periods of 2001 to 2010 was very minimal. This implies that there was little disparity in the amount of rainfall in the last ten years in the study area. In 2001 the amount of rainfall was $1265.2 \mathrm{~mm}$, but this dropped to $1167.9 \mathrm{~mm}$ in 2002 , and increased again in 2003 to $1345.2 \mathrm{~mm}$. The distribution of rainfall varied until 2006 where there was a drastic raise to $1833.8 \mathrm{~mm}$. Between 2007 and 2008 a moderate amount of rainfall was received in the study area. Meanwhile the maximum rainfall was received the in year 2006 implying that the variation in the amount of annual rainfall in Kuta, Niger State was minimal. This variation of the rainfall over the region showed that in the more recent years, higher annual rainfall was received compared to the earlier years implying that the region was becoming more wet.

There was a continuous rise in the yield of yam coming from this area. In $2001-2009$ a steady rise in yield of yam was noticed until 2010 where there was a little drop. This thus shows that there was a minimal variation in yam yield in Kuta community, Niger State Nigeria.

It was also observed that yam yield was very sensitive to rainfall variability. This probably may be due to the fact that most agricultural productions in this area, was rain-fed and that about 95 percent of all cropland of this zone depended on rainfall as the sole source of water supply for crop yield. In these rain-dependent agroecosystems, the interaction of rainfall and other climatic elements determine the availability of water for crop yield.

A statistically significant relationship existed between rainfall variability and yam yield. This goes a long way to indicate that there is an important relationship between rainfall and yam production. This means that rainfall is very important for yam production. 
After the rains haves established it must be evenly distributed for proper growth and enlargement of yam tubers. Consequently yam production is indeed favoured by moderate rainfall that is well spread.

\section{Conclusion}

The yam farmers in the study area are confronted with several problems, notable is that of linking rainfall modifications and yam growing. Most farmers in these areas have adopted some strategies which include not starting their cropping until the latter part of June each year as against late February to early March for starting their farming for yam tubers.

In view of this we would like to suggest that new research be initiated to identify yam varieties that would produce best yield in line with the new time schedule and at the same time invest in surveys that will highlight the best time and crop mixtures that will do well in this agro-ecological environment. The experimented yam crop and their mixtures will be focusing on different dates of rainy seasons and the dates that will give rise to good production for the benefit of crop farmers. This testing naturally has to be implemented with the active contribution of farmers.

\section{References}

[1]. Adejuwon, S.A. (2004). Impacts of Climate Variability and Climate Change on crop Yield in Nigeria. Lead paper presented at the stakeholders workshop on the Assessment of impact and adaptation to climate change, conference center,205-219.

[2]. http://dx.doi:10.1007/BF00867578,

[3]. http://dx.doi.org/10.1007/BF00867578

[4]. Akanbi, W. B., Olabode, O.S., Olaniyi, J.O and Ojo, A.O (2004): Introduction to Tropical Crops. Published by Raflink Compter Eleyele, Ibadan.

[5]. CBN, (Central Bank of Nigeria), 2002. Statistical Bulletin

[6]. Ekunwe P. A, Orewa S. I, Emokaro C. O (2008). Resource use Efficiency in Yam Production in Delta and Kogi State of Nigeria. Asian J. Agric. Res. 2(20):61-69.

[7]. Etim N. A, Udoh E. J, Awoyemi T. T (2005). Measuring Technical efficiency of Urban farms in Uyo Metropolis. Global J. Agric. Sci. 4 (1):91-95.

[8]. FAO (Food and Agricultural organization) 2002. Statistical data. www.fao.org.

[9]. FAO (Food and Agriculture Organization) 2007. F.A. FAO STAT. Statistics Division of Food and Agriculture Organization.

[10]. www. Faostat.org. accessed July 21, 2014.

[11]. NRCRI (National Root Crops Research Institute), 1998. Yam improvement studies. Annual Report of National Root Crops, Research Institute, Umudike.

[12]. Nwosu, C. S and V. B. N. Okoli (2010). Economic Analysis of Resource use by Wase Yam Farmers in Owerri Agricultural zone of Imo State, Nigeria in proceedings of 44th Annual Conference of Agricultural Society of Nigeria held in Ladoke Akintola University 18-22 October, 2010.

[13]. Udoh, E.J., 2005 “Technical Inefficiency in Vegetable Farms of Humid Region? An Analysis of Dry Season Farming by Urban Women in South-South Zone, Nigeria”. J. Agric. Soc. Sci., 1: 80-85

[14]. Udoh, E. J. and Akintola, J. O., (2001). Measurement of the Technical Efficiency of Crop Farms in the South Eastern region of Nigeria. Niger J. Econ. Soc. Stud 43(1): $93-104$.

[15]. Udoh, E. J, Etim N. A. (2007). Application of Stochastic Production frontier in the Estimation of Technical Efficiency of Cassava Based Farms in Akwa Ibom State, Nigeria. Agric. J. 2(6): 731 - 735.

[16]. Xinshen Diao (2010). Economic Importance of Agriculture for Sustainable Development and Poverty Reduction: Findings from a Case Study of Ghana. A paper presented to the Working Party on Agricultural Policy and Markets, 15-17 November 2010. TAD/CA/APM/WP(2010)40.

http://www.oecd.org/tad/agricultural-policies/46341169.pdf 


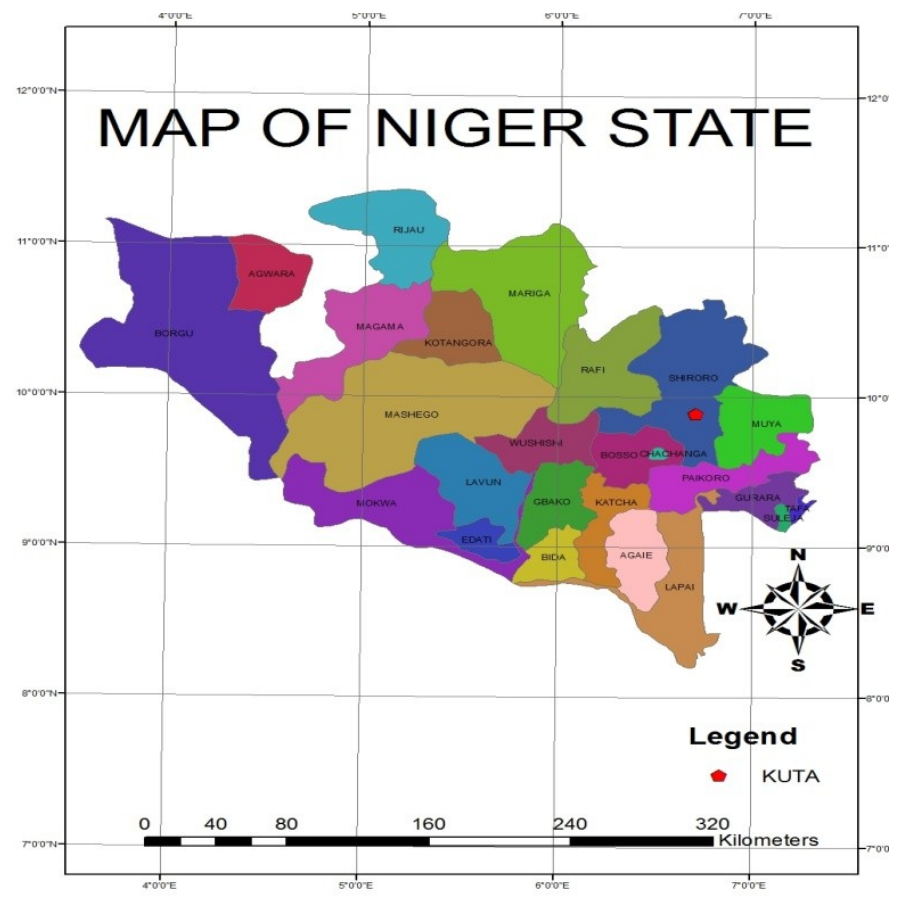

Source; Fayomade M. 2012

Figure.1.1:Niger state showing shiroro local government

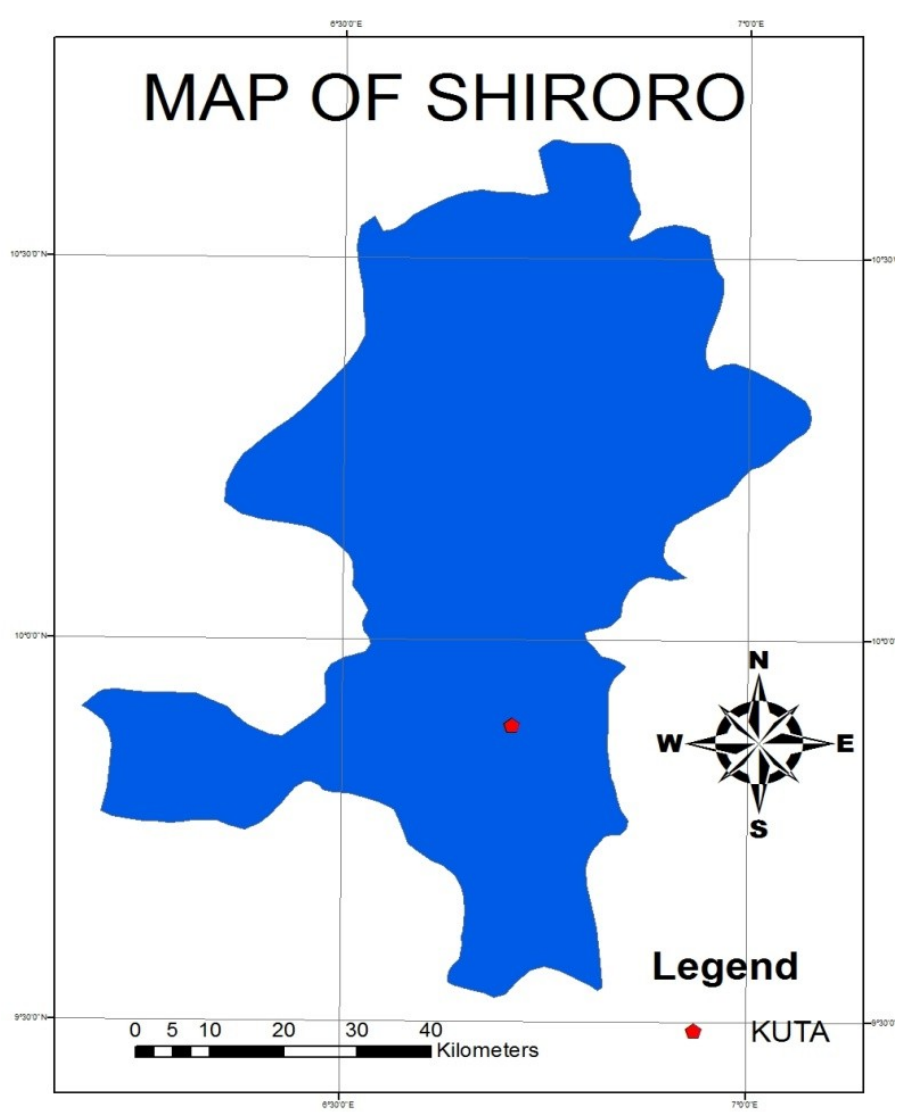

Source; Fayomade M. 2012

Figure.1.2 Shiroro Local Government showing Kuta community 